\title{
Buku Panduan Pelatihan Tanggung Jawab Akademik Melalui Media Topeng Malang
}

\author{
Nofita Puspitasari ${ }^{1}$, Nur Hidayah ${ }^{1}$, Arbin Janu Setiyowati ${ }^{1}$ \\ ${ }^{1}$ Bimbingan dan Konseling-Universitas Negeri Malang
}

\begin{tabular}{l}
\hline \hline INFO ARTIKEL \\
\hline Riwayat Artikel: \\
Diterima: $12-12-2019$ \\
Disetujui: $17-06-2020$ \\
\hline
\end{tabular}

\section{Kata kunci:}

academic responsibility; media mask

tanggung jawab akademik; media topeng

\begin{abstract}
ABSTRAK
Abstract: This study aims to (1) produce a product guide for academic responsibility training with Malang mask media; (2) uncovering the quality of the feasibility of a guidebook for academic responsibility training with the Malang mask media; and (3) know the effectiveness of the academic responsibility training guidebook with Malang mask media. This research development uses the development research method of Borg \& Gall. In the feasibility test stage, data were collected by distributing a feasibility test questionnaire to learning media experts, BK experts, Malang mask culture experts and testing by prospective BK teacher users. The results showed that the use of a guide book on academic responsibility training with Malang mask media was effective in increasing academic responsibility.
\end{abstract}

\begin{abstract}
Abstrak: Penelitian ini bertujuan untuk (1) menghasilkan produk buku panduan pelatihan tanggung jawab akademik dengan media topeng Malang; (2) mengungkap kualitas kelayakan buku panduan pelatihan tanggung jawab akademik dengan media topeng Malang; (3) mengetahui keefektifan buku panduan pelatihan tanggung jawab akademik dengan media topeng Malang. Penelitian pengembangan ini menggunakan metode penelitian pengembangan dari Borg \& Gall. Pada tahap uji kelayakan, data dikumpulkan dengan melakukan penyebaran angket uji kelayakan kepada ahli media pembelajaran, ahli BK, ahli budaya topeng Malang dan pengujian oleh calon pengguna guru BK. Hasil penelitian menunjukkan bahwa penggunaan buku panduan pelatihan tanggung jawab akademik dengan media topeng Malang efektif untuk meningkatkan tanggung jawab akademik.
\end{abstract}

\section{Alamat Korespondensi:}

Nofita Puspitasari

Bimbingan dan Konseling

Universitas Negeri Malang

Jalan Semarang 5 Malang

E-mail: novitapuspitasari6@gmail.com

Kehidupan tidak akan lepas dari menghadapi suatu tantangan. Individu dituntut untuk daapt bersaing dalam menghadapi tantangan tersebut sesuai dengan peran yang diemban. Manusia sebagai makhluk individu harus dapat menjalankan tugasnya untuk memenuhi kebutuhan pribadinya, sedangkan manusia sebagai makhluk sosial harus menjalankan tugasnya dalam berinteraksi dengan orang lain secara positif. Individu yang mampu memenuhi kebutuhannya adalah individu yang memiliki karakter tanggung jawab. Tanggung jawab utama siswa di sekolah adalah tanggung jawab akademik. Bentuk tanggung jawab akademik siswa di sekolah yaitu mengerjakan tugas yang diberikan oleh guru, mengumpulkan pekerjaan rumah tepat waktu, mendengarkan guru yang menerangkan materi pelajaran di depan kelas, dan tidak mencontek saat ujian. Siswa yang sadar akan tanggung jawab akademiknya akan mendorong dirinya menjadi anak yang berkepribadian baik dan peningkatan hasil prestasi belajar. Sesuai dengan pernyataan yang diungkapkan oleh Pasani, Sumartono, Sridevi (2016) bahwa karakter tanggung jawab dan prestasi belajar memiliki pengaruh yang signifikan, artinya apabila siswa memiliki sikap tanggung jawab yang tinggi, maka hasil belajar yang dicapai oleh siswa juga tinggi, sebaliknya jika siswa tidak memiliki sikap tanggung jawab maka prestasi hasil belajarnya juga tidak akan maksimal (Azwar, 2013).

Riset tentang tanggung jawab telah banyak dilakukan di berbagai negara dengan tujuan untuk membentuk siswa yang bertanggung jawab di sekolah (Lewis, 2001). Bila ketertiban dan kepatuhan dilakukan secara berulang, maka akan membentuk sikap sadar terhadap tugas apa yang seharusnya diselesaikan, kesadaran ini yang dimaksud tanggung jawab. Dalam perspektif pendidikan karakter di Indonesia, tanggung jawab merupakan nilai yang harus ditanamkan pada diri siswa, di samping nilai-nilai lain. Penelitian ini menjelaskan bahwa internalisasi nilai lebih difokuskan pada nilai tanggung jawab akademik yang bagi siswa memiliki posisi yang sangat penting karena (1) untuk mencapai keberhasilan studinya di lembaga pendidikan dan (2) merupakan persiapan mereka untuk berperan di masyarakat (Lewis et al., 2015). Dalam konteks yang lebih luas, tanggung jawab merupakan karakter yang penting untuk dimiliki dengan tujuan agar tercapainya sistem pendidikan yang baik. 
Siswa SMP/MTs memiliki persepsi tersendiri terhadap tuntutan tugas akademik yang ada di sekolah. Persepsi siswa tersebut dapat memberikan dampak atau akibat terhadap sikap menolak atau mengabaikan. Sikap menolak dan mengabaikan inilah yang menjadi pemicu siswa melakukan tindakan kurang bertanggung jawab di sekolah (Dimyati \& Mudjiono, 2013). Menurut teori perkembangan kognitif Piaget, siswa SMP/MTs termasuk dalam tahap operasional formal. Tahap dimana anak berada pada usia 11 tahun sampai dewasa. Siswa dalam tahap ini memiliki karakter sudah mampu berpikir, menalar, dan membuat kesimpulan dari informasi yang didapatkan. Pada tahap ini juga individu sudah mampu memahami sesuatu hal seperti nilai, norma dan bukti logis. Sesuai dengan pendapat yang dikemukakan oleh Chadijah \& Agustin (2012) bahwa masa remaja SMP/MTs berlangsung umur 12-22 tahun. Pada masa ini sudah banyak terjadi perkembangan baik fisik maupun psikis dan telah mampu untuk berpikir dewasa. Berdasarkan pemaparan tersebut dapat disimpulkan bahwa seharusnya siswa SMP sudah dapat berpikir dewasa dan dapat bertanggung jawab terhadap nilai-nilai atau aturan yang berlaku di lingkungan sekolahnya.

Solusi penyelesaian dari ahli dalam menangani permasalahan tanggung jawab akademik siswa selama ini diperkuat dengan solusi atau berbagai metode yang digunakan oleh peneliti terdahulu. Terdapat berbagai metode yang dianggap efektif untuk meningkatkan tanggung jawab akademik siswa. Penelitian yang dilakukan oleh Adeyemo (2012) menyatakan bahwa keterampilan guru dalam melakukan manajemen kelas yang efektif memberikan pengaruh positif terhadap sikap tanggung jawab akademik siswa. Hal ini senada dengan pendapat Pranandari et al (2016) bahwa pengelolaan lingkungan belajar berkaitan dengan cara guru mengelola kelas sehingga siswa dapat menerima informasi dari guru. Hubungan keduanya sangat berpengaruh terhadap kelancaran kegiatan belajar mengajar di kelas. Hal ini juga didukung oleh pendapat Setiyowati et al., (2018) yang menyatakan bahwa idealnya proses pembelajaran di dalam kelas harus dapat mengakomodasi keragaman, baik dari perspektif siswa maupun guru, proses pembelajaran menganggap keanekaragaman individu akan menjadi dasar bagi pertumbuhan kesadaran multikultural. Guru berperan penting dalam pertumbuhan iklim akademik budaya di kelas dengan tujuan supaya siswa mampu bertanggung jawab terhadap tugas akademiknya. Berdasarkan pemaparan tersebut dapat disimpulkan bahwa kreativitas guru dalam mengelola kelas sangat memengaruhi sikap tanggung jawab akademik siswa di kelas (Aisyah et al., 2014).

Bimbingan dan konseling saat ini merupakan layanan yang dapat memberikan fasilitas untuk mengembangkan potensipotensi positif individu dalam konteks budaya siswa. Budaya siswa dapat dijadikan sebagai pedoman hidup sehingga kehidupan siswa dapat terarah dan kesuksesan serta keberhasilan dalam belajar dapat dirasakan oleh siswa. Hal ini dapat dilakukan oleh guru BK melalui meaning of life dalam konteks budaya siswa (Ningsih et al., 2017). Melalui meaning of life konselor dapat memberikan pelayanannya kepada seluruh siswa di sekolah termasuk masalah kurangnya tanggung jawab akademik siswa. Layanan pemenuhan meaning of life siswa dapat diberikan oleh konselor melalui teknik bimbingan pribadi maupun kelompok. Hal ini sudah dibuktikan dengan beberapa penelitian, salah satunya penelitian oleh Hidayah et al., (2018) yang membuktikan bahwa teknik pemodelan budaya dapat digunakan untuk membantu meningkatkan meaning of life siswa. Pengembangan layanan model konseling berbasis kearifan lokal untuk meningkatkan meaning of life siswa di Jawa Timur juga telah dikembangkan oleh (Hidayah et al., 2018). Selain itu, Amalia., et al (2017), Hanafi, Hidayah, \& Mappiare (2018) juga membuktikan bahwa budaya siswa memiliki sumber nilai Creative, Experential, dan Attitudional. Berdasarkan penelitian yang sudah ada, peneliti tertarik untuk mengembangkan panduan pelatihan berbasis budaya dalam setting bimbingan kelompok untuk meningkatkan tanggung jawab akademik siswa. Teknik role playing yang digunakan pada penelitian ini, dilaksanakan dengan mengangkat budaya lokal, yakni menggunakan media topeng Malang. Media ini dipilih karena topeng merupakan benda yang memiliki karismatik yang tidak pernah pudar mulai zaman kuno hingga sekarang. Berbagai bentuk, gaya dan teknik pembuatan hingga cara memakai untuk penampilan estetik. Topeng memiliki karismatik dan simbolik yang membuat manusia secara continue mengelaborasi untuk berbagai kebutuhan, baik sebagai benda hias atau perlengkapan seni pertunjukan (Hidajat, 2015). Perkembangan wayang topeng saat ini masih ada di beberapa desa wilayah Malang Kabupaten, yaitu di desa Glagahdawa (Tumpang), desa Kedungmonggo (Pakisaji) dan desa Sumber Pucung (Nurcahyo, 2019).

Kesenian Topeng Malang merupakan pemeranan sebuah drama tari yang dalam setiap gerakannya memberikan sebuah cerita. Cerita dalam tari topeng Malang merupakan cerita/roman Panji yang menggambarkan seorang kesatria yang bijaksana, baik hati dan bertanggung jawab yang dapat dijadikan teladan atau panutan dalam menjalani kehidupan (tulandha laku utama). Dalam cerita Panji banyak ditemukan sifat kepahlawanan, konsep baik dan buruk, cita-cita masyarakat, kejujuran, cinta kasih, tanggung jawab, kebaikan budi, nilai-nilai sosial, dan lain sebagainya. Terdapat suatu ajaran luhur dalam cerita Panji melalui pertunjukan drama tari topeng Malang yang sengaja diperankan untuk menyampaikan pesan nilai-nilai kehidupan yang kemudian diinterpretasi dan dimaknai oleh penonton (audiens). Nilai luhur yang ada disampaikan untuk direduksi menjadi elemen-elemen dalam struktur Topeng Malang, dimana setiap elemennya mempunyai arti konvensional. Beberapa contoh bentuk elemen, misalnya rambut bagian depan distilisasi seperti kupu tarung yang diartikan sebagai karakter pemberani, dan stilisasi mripat jithok diartikan sebagai karakter baik budi. Selain itu, topeng Malang juga memberikan fungsi pendidikan, yaitu untuk memengaruhi tingkah laku seseorang secara kolektif, melalui pesan nilai yang disampaikan (Melany \& Nirwana, 2015). Berdasarkan penjelasan dari penelitian yang sudah ada, dapat disimpulkan bahwa (1) topeng Malang merupakan media yang bisa dijadikan sebagai sarana pembelajaran atau bimbingan dalam bidang pendidikan, (2) cerita Topeng Malang sangat bervariasi dan dapat dikembangkan sesuai dengan kebutuhan, dan (3) tokoh panji dalam cerita topeng Malang memiliki nilai-nilai karakter positif yang dapat dijadikan panutan atau contoh keteladanan dalam menjalani kehidupan. Hal ini membuktikan bahwa topeng Malang dapat digunakan sebagai media untuk meningkatkan sikap tanggung jawab akademik siswa. 
Tanggung jawab akademik merupakan pemahaman akan kesiapan seseorang terhadap kejadian di lingkungannya sebagai upaya pemenuhan kewajiban atau beban yang harus dipenuhi dalam menerima dan menyampaikan pemikiran, ilmu pengetahuan, gagasan serta mengujinya secara leluasa dan terbuka dalam belajar (Dyanasta, 2015). Melalui panduan pelatihan bimbingan kelompok yang dikemas secara menarik dan berbeda menggunakan media topeng malang ini akan membantu konselor lebih cepat menanamkan karakter tanggung jawab akademik siswa. Penggunaan topeng malang sebagai media untuk mentransformasikan nilai-nilai karakter, maupun sikap positif sudah pernah diteliti oleh (Krisphianti et al., 2016), yang telah membuktikan keefektifan penggunaan Topeng Malang sebagai media peningkatan sikap fairness siswa SD dengan teknik storytelling. Penanaman nilainilai pendidikan karakter menggunakan media topeng malang juga diteliti oleh Nafisah (2013) yang telah membuktikan bahwa pelatihan tari topeng malang dapat digunakan sebagai media pendidikan karakter di Padepokan Seni Asmoro Bangun Kedungmonggo Pakisaji Malang. Nilai karakter yang dimaksud adalah (1) percaya Tuhan dan ciptaanNya; (2) mengasah percaya diri; (3) menanamkan nilai tanggung jawab; (4) meningkatkan nilai toleransi pada keberagaman perbedaan yang ada; (5) konsekuen dan terbuka dalam menyelesaikan masalah. Selanjutnya, Hidajat (2015) melakukan penelitian yang bertujuan untuk mengetahui makna, simbol, dan struktur wayang topeng Malang dan hasil penelitian tersebut mengungkapkan bahwa relasi antara realitas dan simbolisasi digolongkan dari tiga tokoh topeng, yaitu (1) tokoh Panji Asmorobangun memiliki nilai kekuasaan, maskulin, gagah berani; (2) tokoh Dewi Sekartaji memiliki sifat nurut, berbakti, feminim dan menyayangi sesama dan (3) tokoh Klana Sewandana memiliki sifat melindungi sesama. Adapun Hidayatullah (2018) mengembangkan tentang buku topeng menggunakan teknik digital painting untuk media pengajaran anak usia 8-12 tahun untuk meningkatkan eksistensi dari kebudayaan lokal dan dapat diteruskan kembali ke generasi muda, meningkatkan minat untuk mempelajari kesenian lokal khususnya kesenian topeng malang. Selain untuk memperkenalkan budaya, Topeng Malang juga dapat digunakan sebagai media edukatif untuk menyampaikan pesan nilai karakter positif yaitu tanggung jawab akademik. Berdasarkan hasil temuan penelitian berkenaan dengan topeng Malang, dapat disimpulkan bahwa (1) penggunaan topeng malang teruji efektif, sebagai media untuk menanamkan nilai karakter moral dan budi pekerti luhur; (2) cerita yang disampaikan dalam topeng malang memberikan modeling sebagai contoh perilaku/hal yang baik dan mencegah untuk melakukan sesuatu yang buruk baik dengan Tuhan, manusia lain dan diri sendiri; (3) penyampaian cerita topeng malang dapat dipahami dari berbagai kalangan bahkan anak SD. Pemaparan tersebut menunjukkan bahwa Topeng Malang layak digunakan sebagai media untuk menampilkan cerita yang bermuatan karakter tanggung jawab akademik.

Hasil studi pendahuluan menyatakan bahwa penanaman karakter tanggung jawab akademik di sekolah masih belum terlalu optimal karena hanya sebatas pengetahuan saja, tanpa diikuti dengan proses kesadaran akan tanggung jawab akademik dalam diri siswa. Oleh karena itu, peneliti bermaksud mengembangkan panduan role playing dengan media topeng Malang untuk meningkatkan tanggung jawab akademik siswa MTs yang nantinya diharapkan dapat menjadi alternatif, dalam memberikan bantuan kepada konselor sekolah untuk memunculkan karakter tanggung jawab akademik pada siswanya. Peneliti memilih judul "Pengembangan Panduan Role Playing dengan media Topeng Malang untuk meningkatkan tanggung jawab akademik siswa MTs" dikarenakan secara teoritik panduan role playing dengan media Topeng Malang untuk meningkatkan tanggung jawab akademik siswa MTs diperlukan dan belum ada yang mengembangkan panduan tersebut di MTsN 1 Kota Malang. Pemilihan teknik role playing dengan media topeng Malang juga didasarkan pada penggunaannya yang telah digunakan secara luas dan secara khusus dalam pendidikan, terutama di Sekolah Menengah Pertama. Selain itu, teknik role playing dengan media Topeng Malang juga berorientasi pada perilaku, prosedurnya dapat dinilai dengan istilah-istilah nyata yang dapat diamati dan diperlukan untuk pengembangan rencana pendidikan siswa dengan mengukur kemajuan atau perubahan yang terjadi. Hasil dari penelitian ini akan menjadi salah satu pengembangan keilmuan dalam pemberian layanan bimbingan kelompok kepada siswa.

\section{METODE}

Metode dalam penelitian ini menggunakan penelitian Research and Development. Penelitian dan pengembangan panduan pelatihan tanggung jawab akademik dengan media topeng Malang ini menggunakan 10 prosedur penelitian dari (Borg \& Gall, 2003). Instrumen yang dipakai oleh peneliti dalam penelitian ini yaitu instrumen penilaian ahli dan calon pengguna, dan skala tanggung jawab akademik siswa. Instrumen yang dipakai dalam penilaian dan evaluasi ini menjadi alat ukur atas produk panduan yang telah dikembangkan. Penilaian-penilaian yang diberikan oleh ahli didasarkan pada aspek-aspek produk sebagai media pembelajaran dan aspek-aspek jabaran dalam variabel pelatihan tanggung jawab akademik siswa. Pengembangan instrumen disesuaikan dengan objek penilaian ahli yang dilibatkan. Terdapat dua instrumen penilaian dan evaluasi ahli (ahli BK dan ahli media), dua instrumen hasil penilaian dan evaluasi guru BK sebagai calon pengguna, dan satu instrumen penilaian dan evaluasi ahli budaya topeng Malang.

Tahap pengembangan produk awal ini dimulai dengan menyusun dan merancang sistematika produk panduan dan desain produk. Penyusunan buku panduan dalam penelitian ini yaitu sampul, ucapan terima kasih, daftar isi, pendahuluan, petunjuk pelatihan, prosedur pelatihan, evaluasi, glosarium, daftar rujukan dan lampiran, sedangkan untuk penyusunan desain produk mencakup (1) pemilihan warna, (2) gambar, (3) kertas yang digunakan, (4) font dan jenis tulisan yang digunakan, dan (5) isi atau materi dalam panduan ini mengadopsi cerita budaya topeng Malang.

Instrumen penilaian ahli disusun sesuai dengan spesifikasi keberterimaan produk, meliputi spesifikasi ketepatan, kejelasan, dan kegunaan. Masing-masing aspek yang ada dalam instrumen akan disusun sesuai dengan spesifikasi keberterimaan produk yang ingin dipenuhi. Sistem penilaian pada instrumen ini menggunakan rating scale. Ahli memberikan angka 1 - 4 . Angka 1 pada 
skala menunjukkan bahwa butir komponen yang ada didalam produk tidak muncul atau tidak memenuhi spesifikasi keberterimaan produk. Pada angka 4 menunjukkan bahwa item komponen telah muncul dengan baik dan memenuhi spesfifikasi keberterimaan produk. Penilaian yang digunakan disesuaikan dengan kriteria yang mencakup (1) kelayakan bahasa, (2) kelayakan isi, (3) kelayakan kegrafikan, dan (4) kelayakan penyajian. Penilaian penyajian, bahasa, dan kegrafikan dapat dilakukan oleh ahli media pembelajaran, sedangkan untuk kelayakan isi panduan dilakukan oleh ahli BK. Hasil analisis data kuantitatif dilakukan interpretasi untuk mengambil kesimpulan dari hasil yang telah didapatkan.

Data kualitatif penilaian dan evaluasi ahli dan calon pengguna dalam bentuk saran, kritik, dan komentar. Data kualitatif dianalisis menggunakan analisis deskriptif-interpretatif oleh peneliti. Secara umum, data kuantitatif dan kualitatif yang diberikan oleh ahli dan calon pengguna untuk memberikan gambaran kepada peneliti mengenai kelayakan produk yang dikembangkan. Penilaian dan evaluasi baik data kuantitatif maupun kualitatif akan menjadi pertimbangan bagi peneliti untuk melakukan perbaikan sesuai dengan hasil penilaian dan evaluasi oleh ahli dan calon pengguna produk. Penilaian oleh ahli BK yaitu 0,85 , penilaian oleh ahli media yaitu 0,99, dan penilaian oleh calon pengguna guru Bimbingan Konseling adalah 0,98 yang artinya hasil ini berada dalam kategori "sangat tinggi”. Buku panduan ini juga telah diuji keefektifannya oleh peneliti dan hasilnya efektif untuk meningkatkan sikap tanggung jawab akademik siswa. Berdasarkan hasil penilaian ahli dan hasil uji keefektifan dapat dikatakan bahwa penelitian yang dilakukan menghasilkan produk yang diterima secara tepat, jelas, dan layak digunakan sebagai buku panduan untuk guru BK.

\section{HASIL}

Produk pengembangan buku panduan pelatihan tanggung jawab akademik dengan teknik role playing menggunakan media topeng Malang untuk siswa MTs melalui tahapan pengkajian format dan isi. Pengkajian format dalam penelitian ini dimulai dari penentuan desain sampul. Sampul panduan pelatihan tanggung jawab akademik dengan teknik role playing menggunakan media topeng Malang didesain dengan kombinasi dari warna hijau, kuning kecoklatan, dan putih. Kombinasi dari warna-warna tersebut menggambarkan makna tokoh Panji adalah tokoh protagonis untuk mengatur konflik dalam cerita. Warna hijau diartikan sebagai tokoh yang baik hati. Karakter sabar, jujur, gesit, perwira, dan bertanggung jawab dapat ditunjukkan pada mata yang berbentuk bulir padi, sedangkan bibirnya berbentuk sedikit terbuka yang artinya lembut dan berbudi luhur. Titik emas pada bentuk alisnya menunjukkan keturunan dewa. Alisnya berbentuk nanggal sepisan, hindungnya berbentuk mancung, dan memiliki kumis. Buku panduan ini juga akan diberikan quotes tentang tanggung jawab akademik siswa di setiap pertemuan pelatihan untuk memotivasi siswa sehingga memberikan kesan kemenarikan dan tidak membosankan. Pengkajian format tidak hanya berfokus pada pemilihan warna yang digunakan, tetapi juga tentang gambar yang ada dalam sampul. Gambar yang digunakan dalam sampul depan panduan adalah gambar lima tokoh topeng yang akan menjadi media role playing (Panji Asmorobangun, Dewi Sekartaji, Bapang, Ragil Kuning, dan Semar). Pengkajian format juga dilakukan berkaitan dengan bahan atau kertas dan ukuran kertas yang digunakan dalam panduan ini. Panduan ini menggunakan kertas yang berukuran 18,2 cm x 25,7 cm (B5). Pemilihan bahan yang digunakan untuk sampul yaitu kertas Artpaper Glossy 120 gram, sedangkan untuk bagian isi panduan, kertas yang digunakan yaitu kertas HVS 80 gram. Pengkajian bentuk dan desain panduan telah melalui proses pertimbangan-pertimbangan baik dari sisi keindahan, kepraktisan, dan harga untuk menghasilkan produk panduan yang sangat menarik, tepat, dan berguna.

Produk panduan pelatihan tanggung jawab akademik dengan teknik role playing menggunakan media topeng Malang untuk siswa MTs telah dilakukan uji coba yang mencakup (1) pengujian tahap awal dilaksanakan kepada ahli media pembelajaran dan ahli BK. Ahli media memberikan penilaian terhadap ketepatan, kejelasan, dan kegunaan format panduan sedangkan ahli bimbingan dan konseling memberikan penilaian terhadap ketepatan, kejelasan, dan kegunaan isi materi panduan, (2) uji coba oleh ahli budaya yang memberikan penilaian terhadap ketepatan, kejelasan, dan kegunaan cerita budaya dalam topeng Malang, (3) pengujian kepada calon pengguna yang dilakukan kepada guru Bimbingan Konseling untuk mendapatkan nilai ketepatan, kejelasan, dan kegunaan panduan baik dari segi format dan isi materi, dan (4) uji keefektifan yang dilakukan dengan melibatkan 15 siswa kelas VII.

Paparan data uji coba validasi dari ahli bimbingan konseling, ahli media pembelajaran, ahli budaya topeng malang, dan uji calon pengguna/guru BK merupakan data pendukung untuk menguji tingkat keberterimaan produk. Hasil sajian data uji ahli akan direkapitulasi untuk mempermudah mengetahui tingkat keberterimaan produk secara keseluruhan. Rekapitulasi tingkat keberterimaan produk tersaji pada tabel 1 .

Tabel 1. Rekapitulasi Hasil Penilaian Uji Validasi Produk

\begin{tabular}{|c|c|c|c|c|c|c|}
\hline \multirow{2}{*}{ No. } & \multirow{2}{*}{ Subjek Uji Ahli } & \multicolumn{5}{|c|}{ Skor Perolehan Produk Panduan Role Playing } \\
\hline & & Aspek Ketepatan & Aspek Kejelasan & Aspek Kegunaan & Total Skor & Interpretasi \\
\hline 1. & Ahli bK & 0,83 & 0,83 & 0,89 & 0,85 & Sangat Tinggi \\
\hline 2. & Ahli Media Pembelajaran & 0,98 & 0,98 & 1,00 & 0,99 & Sangat Tinggi \\
\hline 3. & Ahli Budaya Topeng Malang & 0,67 & 0,67 & 0,78 & 0,83 & Sangat Tinggi \\
\hline 4. & Calon Pengguna Produk (Guru BK) & 0,97 & 1,00 & 0,97 & 0,98 & Sangat Tinggi \\
\hline
\end{tabular}


Berdasarkan tabel 1 dapat dilihat hasil rekapitulasi tingkat keberterimaan produk dari uji ahli. Indeks validitas ketepatan, kejelasan dan kegunaan yang diperoleh menunjukkan bahwa panduan pelatihan tanggung jawab akademik dengan teknik role playing menggunakan media topeng Malang untuk siswa MTs ini dapat dinyatakan sebagai media bimbingan yang sangat layak untuk membantu pemberian layanan oleh guru Bimbingan dan Konseling. Setelah mendapat penilaian dari para ahli, langkah berikutnya peneliti melakukan uji keefektifan buku panduan kepada siswa kelas VII berjumlah 15 orang. Lima belas siswa dipilih secara acak berdasarkan hasil studi pendahuluan yang dilakukan dengan menyebarkan angket skala tanggung jawab akademik kepada siswa dan hasil pengklasifikasian berada pada tingkatan sedang dan rendah. Uji keefektifan produk dilakukan menggunakan one-group pretest-posttest design. Untuk mendapatkan hasil pretest maka dilakukan penyebaran instrumen skala tanggung jawab akademik yang sudah diuji validitas dan reliabilitas. Untuk mengetahui sebaran skor pretest dan skor posttest dapat dilihat pada grafik gambar 1 .

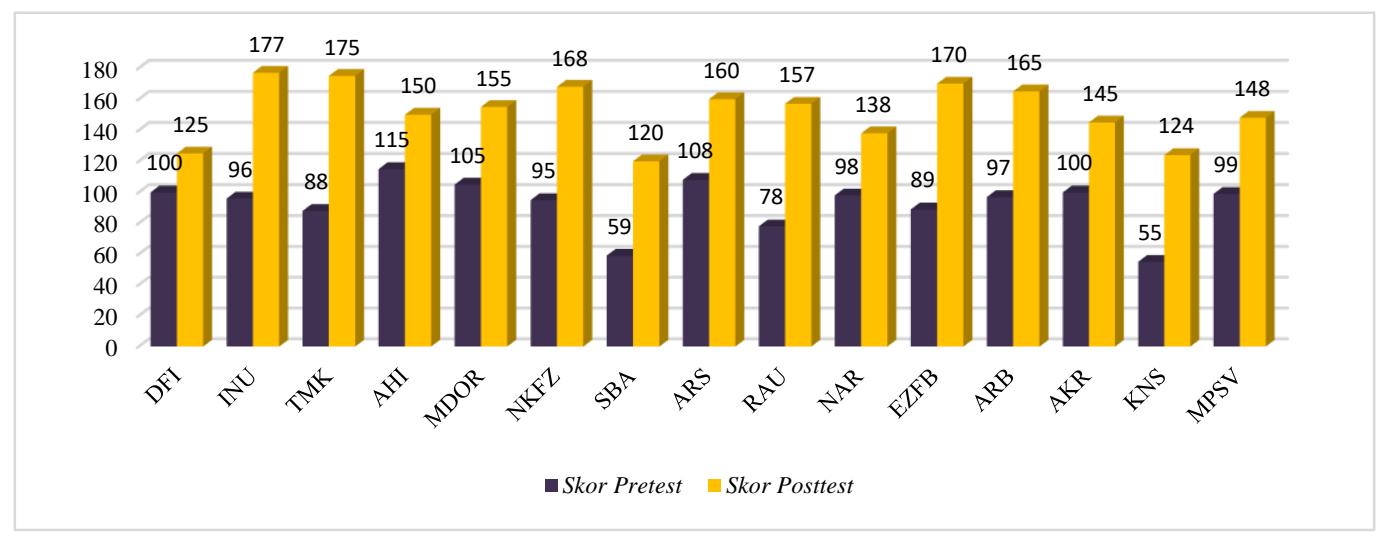

\section{Gambar 1. Grafik Distribusi Frekuensi Skor Pretest dan Skor Posttest Tanggung Jawab Akademik Siswa}

Berdasarkan hasil skor pretest dan skor posttest yang telah didapatkan, selanjutnya dilakukan analisis dengan uji statistik non-parametrik menggunakan metode analisa The Wilcoxon Signed-rank test melalui aplikasi IBM SPSS versi 21 untuk windows yang bertujuan untuk mengetahui signifikansi perubahan antara sebelum dan sesudah pemberian perlakuan yang terjadi pada sasaran. Hasil pengujian Wilcoxon Signed-rank test tersaji pada tabel 2.

Tabel 2. Hasil Pengujian Wilcoxon Signed-Rank Test

\begin{tabular}{|c|c|c|c|c|}
\hline \multicolumn{5}{|c|}{ Ranks } \\
\hline \multirow{5}{*}{ Posttest - Pretest } & & $\mathbf{N}$ & Mean Rank & Sum of Ranks \\
\hline & Negative Ranks & $0^{\mathrm{a}}$ & .00 & .00 \\
\hline & Positive Ranks & $15^{\mathrm{b}}$ & 8.00 & 120.00 \\
\hline & Ties & $0^{\mathrm{c}}$ & & \\
\hline & Total & 15 & & \\
\hline a. Posttest < Pretes & & & & \\
\hline b. Posttest $>$ Pretes & & & & \\
\hline c. Posttest $=$ Pretes & & & & \\
\hline
\end{tabular}

\begin{tabular}{ll} 
Test Statistics & \\
\hline & Posttest - Pretest $^{\mathbf{a}}$ \\
$\mathrm{Z}$ & $-3.408^{\mathrm{b}}$ \\
Asymp. Sig. (2-tailed) & .001 \\
\hline \multicolumn{2}{l}{ a. Wilcoxon Signed Ranks Test } \\
b. Based on negative ranks. \\
\hline
\end{tabular}

Berdasarkan hasil di atas, dapat diinterpretasikan Negative Ranks atau selisih (negatif) yang diperoleh adalah 0 yang dapat disimpulkan tidak adanya pengurangan (penurunan) dari skor pretest ke skor posttest. Positive Ranks atau selisih (positif) yang diperoleh adalah 15 yang dapat disimpulkan bahwa 15 siswa mengalami hasil peningkatakan tanggung jawab akademik dari nilai pretest ke nilai posttest. Ties adalah kesamaan nilai pretest dan nilai posttest yaitu 0 yang dapat disimpulkan bahwa tidak ada nilai yang sama antara nilai pretest dan nilai posttest. Interpretasi berikutnya yaitu berdasarkan hasil Test Statistics di atas, dapat diketahui hasil Asymp. Sig. (2-tailed) yaitu 0,001. Hasil menunjukkan ada perbedaan hasil pretest dan posttest pada tanggung jawab akademik siswa atau dapat dinyatakan bahwa ada pengaruh pelatihan peningkatan tanggung jawab akademik dengan media topeng Malang dikarenakan nilai yang didapatkan yaitu 0,001 lebih kecil dari 0,05. 
Penilaian selanjutnya yaitu dengan uji paired t-test. Untuk menggunakan uji paired t-test maka data yang dipakai harus berdistribusi normal. Oleh sebab itu, untuk mengetahui data sudah memiliki distribusi normal. Hasil yang diperoleh dari uji normalitas yang telah dilakukan terdapat pada tabel 3.

Tabel 3. Hasil Uji Normalitas

\begin{tabular}{llll}
\multicolumn{2}{l}{ One-Sample Kolmogorov-Smirnov Test } & & \\
\hline \multirow{2}{*}{ N } & & Pretest & Posttest \\
Normal Parameters & & 15 & 15 \\
& Mean & 92.13 & 151.80 \\
& Std. Deviation & 16.681 & 18.521 \\
Most Extreme Differences & Absolute & .235 & .126 \\
& Positive & .119 & .126 \\
Kolmogorov-Smirnov Z & Negative & -.235 & -.102 \\
Asymp. Sig. (2-tailed) & & .910 & .488 \\
\hline a. Test distribution is Normal. & & .379 & .971 \\
\hline
\end{tabular}

a. Test distribution is Normal.

b. Calculated from data.

Berdasarkan data diatas diperoleh nilai Asymp. Sig. (2- tailed) pretest yaitu 0,379 dan posttest yaitu 0,971. Hal tersebut menunjukkan bahwa data telah memiliki distribusi normal karena lebih dari 0,05. Selanjutnya, karena data sudah memiliki hasil distribusi normal selanjutnya pengujian paired t-test dapat dilakukan. Hasil uji paired t-test yang telah dilakukan terdapat pada tabel 4.

Tabel 4. Hasil Uji Paired T-Test

Paired Samples Test

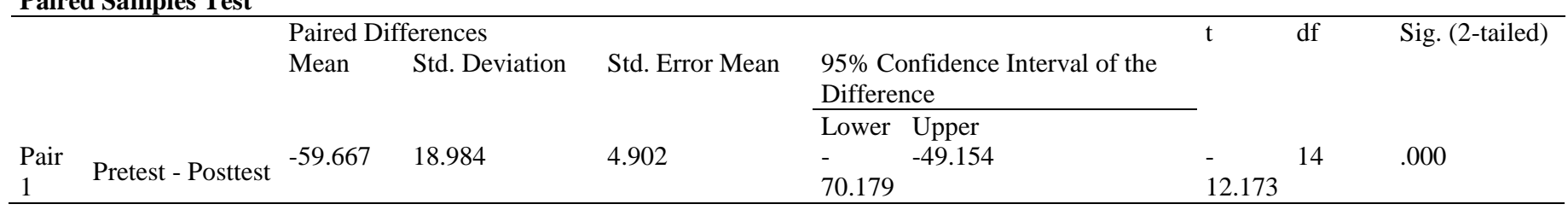

Berdasarkan hasil pengujian paired t-test menggunakan bantuan IBM SPSS Versi 21 untuk windows diperoleh nilai Sig. (2-tailed) yaitu 0,000 . Hal ini menyatakan bahwa terdapat perbedaan yang signifikan terhadap perlakuan yang telah diberikan karena hasil yang diperoleh kurang dari 0,05. Sesuai dengan kriteria uji jika Sig. (2-tailed) lebih kecil dari 0,05 ini berarti terjadi peningkatan setelah diberikan perlakuan (Yuliana, 2018).

Data hasil uji keefektifan tidak hanya didapatkan berdasarkan pada data peningkatan tanggung jawab akademik siswa, tetapi juga berdasarkan pada keefektifan panduan saat digunakan oleh guru BK untuk melatihkan tanggung jawab akademik. Adapun data-data yang didapatkan di lapangan, mencakup (1) guru BK telah melakukan seluruh tahapan sesuai dengan prosedur pelatihan yang ada dalam buku panduan, (2) pada setiap pertemuan seluruh siswa hadir mengikuti pelatihan, tanpa ada yang absen, (3) pada setiap pertemuan seluruh siswa memiliki pengalaman menjadi pemain ataupun observer, bahkan ada siswa yang menawarkan diri untuk menjadi narrator, dan (4) guru BK dapat menggunakan panduan ini dengan baik dan mudah.

\section{PEMBAHASAN}

Sebagaimana telah dirumuskan bahwa tujuan penelitian ini adalah mengembangkan buku panduan pelatihan tanggung jawab akademik dengan media topeng Malang dan melakukan uji coba ahli dan uji keefektifan produk. Berdasarkan tujuan itu, maka dalam penelitian ini berhasil dikembangkan panduan pelatihan tanggung jawab akademik dengan media topeng malang yang telah teruji validasi oleh ahli ahli BK, ahli media pembelajaran, ahli budaya topeng malang, calon pengguna produk oleh guru BK dan uji keterbacaan siswa MTs, serta telah teruji keefektifannya. Produk pengembangan yang telah tervalidasi dikaji secara lebih rinci baik dari sisi format, isi, dan keefektifan.

Produk ini telah melalui proses validasi yang pertama, yaitu bentuk dan layout desain panduan. Validasi format dilakukan oleh dua ahli media pembelajaran yang telah memenuhi kriteria yang ditetapkan oleh peneliti. Hal ini sesuai dengan pernyataan (Juita, 2017) bahwa validasi panduan yang dilakukan oleh ahli bertujuan untuk memberikan penilaian dan menentukan kelayakan dari panduan yang telah dikembangkan. Buku panduan yang digunakan dalam pembelajaran diharapkan memiliki kualitas yang baik karena panduan yang digunakan dalam proses pemberian layanan dapat memberikan pengaruh kualitas guru dan kualitas siswa dalam proses pelaksanaannya (Basuki, Rakhmawati, \& Hastuti, 2015). 
Penilaian keberterimaan format panduan dari ahli media pembelajaran berdasarkan pada indikator-indikator yang telah disusun oleh peneliti. Indikator-indikator tersebut mencakup ketepatan bahasa, ketepatan kegrafikan, ketepatan penyajian, kejelasan warna, dan kejelasan tulisan. Indikator ketepatan tersebut didasarkan pada PP No.19/2005 Pasal 43 ayat (5): "kelayakan bahasa, isi, penyajian, dan kegrafikan buku pembelajaran yang dinilai oleh BSNP dan telah ditetapkan dalam Peraturan Menteri. Peraturan Pemerintah tersebut menjelaskan bahwa kriteria kelayakan media pembelajaran berupa buku terdapat pada kelayakan bahasa, isi, kegrafikan, dan penyajian.

Tampilan buku panduan ini berukuran $18,2 \mathrm{~cm}$ x $25,7 \mathrm{~cm}$ (B5) yang merupakan standar ISO dan JIS (BSNP, 2006), sampul berbahan dasar Artpaper Glossy 120gram yang menunjukkan hasil cetak dan ketebalan yang bagus sehingga tidak mudah rusak. Halaman isi menggunakan kertas HVS 80 gram dengan tujuan agar hasil cetak menunjukkan kualitas bagus dan tidak terlalu tipis. Ukuran tulisan yang dipilih adalah 12 pt dengan bentuk font menggunakan Times New Roman dengan paragraf rata kiri kanan. Paragraf rata kanan kiri yang digunakan sangat membantu para pembaca untuk memahami bacaan dengan teks panjang, paragraf tersebut juga dapat mempermudah pembaca menjaga konsentrasi saat membaca (Abidin, 2014).

Penilaian panduan pada aspek kejelasan yang diberikan oleh ahli media memiliki nilai validasi sangat tinggi karena panduan merupakan media pembelajaran yang memiliki kegunaan bagi guru BK maupun siswa. Hal ini sesuai dengan hasil temuan Rahmaibu et al., (2016) bahwa media pembelajaran dapat dipakai sebagai sumber belajar sehingga dapat membantu guru menjelaskan materi dan menciptakan kondisi yang memungkinkan dapat menerima pengetahuan dan keterampilan sehingga panduan pelatihan tanggung jawab akademik dengan teknik role playing menggunakan media topeng malang memenuhi syarat dalam aspek kejelasan produk.

Produk ini telah melalui proses validasi yang kedua yaitu validasi tentang isi panduan. Validasi isi dilakukan oleh dua ahli BK yang telah memenuhi kriteria sesuai dengan yang ditetapkan. Kelayakan isi materi dalam panduan didasarkan pada hasil penelitian-penelitian terdahulu yang menyatakan bahwa materi yang ada dalam panduan yang mencakup memahami peran diri sebagai pelajar, mengatur diri sebagai pelajar, melaksanakan tugas dan kewajiban sebagai pelajar, memahami peran dan mengatur diri sebagai pelajar secara bertanggung jawab dan memahami peran, mengatur diri dan melaksanakan tugas dan kewajiban sebagai pelajar yang bertanggung jawab memiliki pengaruh yang signifikan dalam meningkatkan sikap tanggung jawab akademik siswa disampaikan oleh (Istati, 2014), (Kamaruzzaman, 2016), Irhami (2017), dan Sartono (2014).

Kelayakan panduan pelatihan tanggung jawab akademik dengan teknik role playing menggunakan media topeng malang untuk siswa MTs didasarkan pada penelitian-penelitian sebelumnya yang turut menghasilkan panduan pelatihan. Penelitianpenelitian tersebut dilakukan oleh Krisphianti et al., (2016), Sartono (2016) \& Setiawati (2012) yang menyatakan bahwa teknik role playing efektif untuk meningkatkan sikap tanggung jawab belajar siswa. Berdasarkan hasil penelitian tersebut, dapat dikatakan bahwa produk ini dapat digunakan oleh guru BK. Selain itu, pemilihan media topeng malang sebagai media layanan bimbingan kelompok juga telah dibuktikan efektif untuk media peningkatan pendidikan karakter siswa dengan hasil penelitian terdahulu oleh (Nirwana, 2015), (Krisphianti et al., 2016), dan Nafisah (2013).

Penilaian panduan pada aspek kejelasan yang diberikan oleh ahli BK memiliki nilai validasi sangat tinggi sehingga panduan pelatihan tanggung jawab akademik dengan teknik role playing menggunakan media topeng malang memenuhi syarat dalam aspek kegunaan produk. Hal ini sesuai dengan pernyataan Setiawati (2012) yang telah membuktikan bahwa implementasi role playing efektif dalam meningkatkan hasil belajar. Utami \& Setiyowati (2016) juga telah mengembangkan panduan permainan edukasi dan hasilnya efektif untuk mengembangkan karakter kepedulian sosial. Selain mendapatkan nilai karakter tanggung jawab akademik, siswa juga telah mampu menunjukkan sikap kepedulian sosial dengan terlibat aktif dengan teman-temannya saat kegiatan role playing sehingga panduan pelatihan tanggung jawab akademik dengan teknik role playing menggunakan media topeng malang memiliki nilai kejelasan jika diterapkan untuk siswa.

Penilaian panduan pada aspek kegunaan yang diberikan oleh ahli BK memiliki nilai validasi sangat tinggi, karena panduan yang dikembangkan memenuhi syarat dalam aspek kegunaan produk. Hal ini sesuai dengan pernyataan Sartono (2016) dalam penelitiannya membuktikan bahwa metode layanan penguasaan konten dengan teknik role playing efektif untuk meningkatkan tanggung jawab belajar siswa SMP menyediakan prosedur dan arah pembelajaran yang tepat sehingga siswa dapat menerapkan pengalaman yang diperoleh pada waktu atau konteks yang tepat. Selain itu, penelitian yang dilakukan oleh (Setyowati \& Simon, 2018) yang telah mengembangkan komik moral sebagai media layanan informasi bagi siswa SMP dan hasilnya menunjukkan bahwa komik moral yang dikembangkan terbukti valid dan layak digunakan oleh guru BK sebagai alternatif media pelayanan BK yang menarik perhatian siswa. Selain itu, media yang menarik dapat memancing pikiran imajinatif siswa dalam memahami konsep dan pesan moral yang disampaikan. Oleh karena itu, panduan pelatihan tanggung jawab akademik dengan teknik role playing menggunakan media Topeng Malang memenuhi syarat dalam aspek kegunaan produk.

Berdasarkan hasil penilaian panduan pelatihan tanggung jawab akademik dengan teknik role playing menggunakan media Topeng Malang yang dilakukan oleh kedua ahli BK, maka dapat disimpulkan bahwa panduan yang dikembangkan memenuhi kriteria keberterimaan pada aspek ketepatan, aspek kejelasan, dan aspek kegunaan produk. Pada penilaian panduan pelatihan tanggung jawab akademik dengan teknik role playing menggunakan media topeng malang untuk siswa MTs terdapat beberapa saran perbaikan yang diberikan oleh kedua ahli. Penilaian produk juga dilakukan oleh ahli budaya topeng Malang. Berdasarkan hasil penilaian panduan pelatihan tanggung jawab akademik dengan teknik role playing menggunakan media Topeng Malang untuk siswa MTs oleh ahli budaya Topeng Malang maka dapat disimpulkan bahwa panduan yang dikembangkan memenuhi kriteria keberterimaan pada aspek ketepatan, aspek kejelasan, dan aspek kegunaan produk. Penilaian produk juga dilakukan oleh dua 
guru BK sebagai calon pengguna produk. Berdasarkan hasil penilaian panduan pelatihan tanggung jawab akademik dengan teknik role playing menggunakan media topeng malang untuk siswa MTs oleh kedua calon pengguna panduan maka dapat disimpulkan bahwa panduan yang dikembangkan memenuhi kriteria keberterimaan pada aspek ketepatan, aspek kejelasan, dan aspek kegunaan produk. Calon pengguna panduan memberikan saran perbaikan mengenai format penilaian rentang seharusnya dijabarkan menggunakan klasifikasi skor total. Hal ini sesuai dengan pernyataan Whiston (2017) bahwa pengklasifikasian skor dalam instrumen asesmen harus disesuaikan dengan jumlah butir yang digunakan untuk mengukur indikator agar hasil yang didapatkan sesuai dengan kebutuhan yang diharapkan.

\section{SIMPULAN}

Kajian-kajian yang telah dipaparkan tentang panduan pelatihan tanggung jawab akademik dengan teknik role playing menggunakan media topeng Malang untuk siswa MTs dapat diambil kesimpulan sebagai berikut. Pertama, produk panduan yang telah peneliti kembangkan berdasarkan keberterimaan format yang meliputi ketepatan bahasa, ketepatan kegrafikan, ketepatan penyajian, kejelasan warna, dan kejelasan tulisan maka dapat disimpulkan bahwa panduan ini sangat tepat, jelas, dan layak digunakan sebagai media bimbingan oleh guru BK. Kedua, Produk panduan yang telah dikembangkan berdasarkan keberterimaan isi, meliputi sampul, ucapan terima kasih, pendahuluan, petunjuk pelatihan, prosedur pelatihan, evaluasi, dan daftar rujukan maka dapat disimpulkan bahwa panduan ini sangat tepat, jelas, dan layak digunakan sebagai strategi bimbingan oleh guru BK. Ketiga, produk panduan yang telah dikembangkan berdasarkan uji keefektifan menunjukkan bahwa teknik role playing dengan media topeng Malang memberikan perubahan yang signifikan untukmeningkatkan tanggung jawab akademik siswa. Bukti ini menunjukkan bahwa panduan ini efektif untuk meningkatkan tanggung jawab akademik siswa MTs.

Dalam pemanfaatan panduan pelatihan tanggung jawab akademik dengan teknik role playing menggunakan media topeng Malang untuk siswa MTs, terdapat beberapa saran yang harus diperhatikan oleh guru BK sebagai pengguna produk. Saran yang dimaksud yaitu sebagai berikut. Pertama, panduan ini merupakan salah satu alternatif media bimbingan kelompok yang bertujuan untuk meningkatkan tanggung jawab akademik siswa. Oleh sebab itu, guru BK hendaknya memahami prosedur dan materi bimbingan yang terdapat dalam panduan ini agar dapat membantu siswa mencapai tujuannya yaitu memiliki tanggung jawab akademik yang tinggi sehingga dapat meraih prestasi belajar. Guru BK juga dapat menambah referensi-referensi terkait dengan tanggung jawab akademik dan teknik role playing dengan media topeng Malang untuk memberikan pemahaman lebih. Kedua, guru BK hendaknya melakukan tindak lanjut dengan pengamatan atau monitoring kepada siswa setelah melakukan proses pelatihan. Ketiga, pengembangan panduan ini dilakukan melalui uji keefektifan terbatas yaitu hanya pada siswa kelas VII di MTsN 1 Kota Malang. Oleh sebab itu, saran untuk pengembangan lebih lanjut sebaiknya dilakukan uji keefektifan dengan melibatkan lebih dari satu sekolah dan subjek yang lebih banyak sehingga memungkinkan akan semakin memperkuat keefektifan produk pada penelitian tindakan BK.

\section{DAFTAR RUJUKAN}

Abidin, Y. (2014). Desain Sistem Pembelajaran dalam Konteks Kurikulum 2013. Bandung: Refika Aditama.

Adeyemo, S. A. (2012). The Relationship Between Effective Classroom Management and Students Academic Achievement. Aisyah, A., Nusantoro, E., \& Kurniawan, K. (2014). Meningkatkan Tanggung Jawab Belajar melalui Layanan Penguasaan Konten. Indonesian Journal of Guidance and Counseling: Theory and Application, 3(3 SE-Articles). https://doi.org/10.15294/ijgc.v3i3.3783

Amalia, M., Hidayah, N., \& Fauzan, L. (2017). Meaning of Life Siswa Sekolah Menengah Pertama dengan Latar Belakang Budaya Samin. Jurnal Kajian Bimbingan dan Konseling, 2(3), 97-106.

Azwar, S. (2013). Sikap Manusia dan Pengukurannya. Yogyakarta: Pusat Belajar Offset.

Borg, W. R., \& Gall, M. (2003). Education Research: An Introduction (7th Edition). USA: Pearson Education, Inc.

Breunig, M. (2005). Turning Experiential Education and Critical Pedagogy Theory Into Praxis. Journal of Experiential Education, 28(2), 106-122.

Cannata, M. A., Smith, T. M., \& Taylor Haynes, K. (2017). Integrating Academic Press and Support by Increasing Student Ownership and Responsibility. AERA Open, 3(3), 2332858417713181.

Chadijah, \& Agustin. (2012). Bimbingan Kelompok Teknik Role Playing untuk Meningkatkan Kedisiplinan Siswa di Sekolah Kelas VIII SMPN 26 Surakarta Tahun Pelajaran 2011/2012. Jurnal Psikologi Pendidikan dan Bimbingan Surakarta: Universitas Negeri Surakarta., 6(1), 49-53.

Dimyati., \& Mudjiono. (2013). Belajar dan Pembelajaran. Jakarta: Rineka Cipta.

Dockery, D. J. (2012). School Dropout Indicators, Trends, and Interventions for School Counselors. Journal of School Counseling, 10(12), 12.

Duijf, H. (2018). Responsibility Voids and Cooperation. Philosophy of the Social Sciences, 48(4), 434-460.

Dyanasta, R. (2015). Keefektifan Klarifikasi Nilai untuk Meningkatkan Kesadaran Nilai Tanggungjawab Akademik pada Siswa. Jurnal Psikopedagogia, 4(2), 132-146.

Fitria, N. (2013). Model Bimbingan Kelompok Berbasis Falsafah Hidup Masyarakat Lampung untuk Mengurangi Prasangka Sosial. Jurnal Bimbingan Konseling, 2(2), 71-78. 
Haryani, H. (2018). Meningkatkan Kemampuan Menyusun Rencana Pelaksanaan Layanan Bimbingan Klasikal (RPL BK) melalui Supervisi Akademik bagi Guru Bimbingan Konseling di Kalimantan Selatan. Jurnal Bimbingan dan Konseling Ar-Rahman, 3(2), 50-55.

Hebert, A., \& Hauf, P. (2015). Student Learning Through Service Learning: Effects on Academic Development, Civic Responsibility, Interpersonal Skills, and Practical Skills. Active Learning in Higher Education, 16(1), 37-49.

Hidajat, R. (2015). Makna Simbolik Wayang Topeng Malang. Malang: Surya Pena Gemilang.

Hidayah, N. (2016). Keefektifan Teknik Sinema Edukasi untuk Meningkatkan Sikap Asertif Siswa MTs Negeri Malang I. Jurnal Pendidikan dan Pembelajaran (JPP), 21(2), 165-172.

Hidayah, N., Ramli, M., \& Hanafi, H. (2018). East Java Modeling Techniques to Improve Student Meaning of Life. 3rd International Conference on Educational Management and Administration (CoEMA 2018).

Hidayatullah, R. A. (2018). TA: Perancangan Buku Ilustrasi Topeng Malangan dengan Teknik Digital Painting sebagai Media Pembelajaran Anak Usia 8-12 Tahun. Institut Bisnis dan Informatika STIKOM Surabaya.

Hotifah, Y., \& Setyowati, A. J. (2018). Konseling Sebaya dalam Persepektif Pesantren. KARYA DOSEN Fakultas Ilmu Pendidikan UM.

Istati, M. (2014). Perbandingan Metode Dialog Sacrotes dan Focus Discusssion untuk Meningkatkan Tanggung Jawab Akademik Siswa SMP. Tesis tidak diterbitkan. Universitas Negeri Malang, Malang.

Juita, T. (2017). Analisis Kelayakan Buku Teks Siswa IPA Kurikulum 2013 pada Materi Sistem Pencernaan Kelas VIII untuk Digunakan Dalam Proses Pembelajaran Ditinjau dari Relevansi Isi, Ketepatan dan Kompleksitas. BIO EDUCATIO:(The Journal of Science and Biology Education), 2(1).

Kamaruzzaman, K. (2016). Analisis Keterampilan Komunikasi Interpersonal Siswa. Jurnal Konseling Gusjigang, 2(2), 202210.

Krisphianti, Y. D., Hidayah, N., \& Irtadji, M. (2016). Efektivitas Teknik Storytelling menggunakan Media Wayang Topeng Malang untuk Meningkatkan Karakter Fairness Siswa Sekolah Dasar. Psikopedagogia Jurnal Bimbingan dan Konseling, $5(1), 17-23$.

Kusumadewi, K. R., Sedanayasa, G., \& Antari, N. N. M. (2014). Efektivitas Konseling Gestalt dengan Teknik "Saya Bertanggung Jawab Atas...." untuk Meningkatkan Tanggung Jawab Akademik Siswa. Jurnal Ilmiah Bimbingan Konseling Undiksha, 2(1).

Lewis, S. V, Robinson III, E. H., \& Hays, B. G. (2015). Implementing An Authentic Character Education Curriculum. Childhood Education, 87(4), 227-231.

Melany., \& Nirwana, A. (2015). Kajian Estetik Topeng Malangan (Studi Kasus di Sanggar Asmorobangun, Desa Kedungmonggo, Kec. Pakisaji, Kab. Malang). Imaji: Jurnal Seni dan Pendidikan Seni, 13(2), 1-19. DOI: https://doi.org/10.21831/imaji.v13i2.7881

Ningsih, Y. M. C. R., Hidayah, N., \& Lasan, B. B. (2017). Studi Meaning of Life Siswa Sekolah Menengah Pertama Etnis Tengger. Jurnal Kajian Bimbingan dan Konseling, 2(2), 76-85.

Novita, L., \& Hidayah, N. (2016). Pengembangan Panduan Pelatihan Efikasi Diri Dalam Hubungan Pertemanan melalui Strategi Experiential Learning bagi Siswa SMP. Jurnal Kajian Bimbingan dan Konseling, 1(2), 79-89.

Pasani, C. F., Sumartono., \& Sridevi, H. (2016). Mengembangkan Karakter Tanggung Jawab Siswa melalui Pembelajaran Model Kooperatif Tipe Number Head Together. EDU-MAT: Jurnal Pendidikan Matematika, 4(2), 1-10. DOI: http://dx.doi.org/10.20527/edumat.v4i2.2579

Pranandari, I. W., Degeng, I. N. S., \& Hanurawan, F. (2016). Korelasi Antara Persepsi Siswa tentang Pengelolaan Kelas, Hubungan Teman Sebaya (Peer Relationships), dan Hasil Belajar Siswa Kelas IV SD Negeri Kecamatan Sananwetan Kota Blitar. Jurnal Pendidikan: Teori, Penelitian, dan Pengembangan, 1(3), 480-485.

Prasetiyo, N. A., \& Perwiraningtyas, P. (2017). Pengembangan Buku Ajar Berbasis Lingkungan Hidup pada Matakuliah Biologi di Universitas Tribhuwana Tunggadewi. Jurnal Pendidikan Biologi Indonesia, 3(1), 19-27.

Putra, G. I., \& Sutarno, W. D. (2013). Teknik Role Playing untuk Meningkatkan Kemampuan Komunikasi Antar Pribadi Siswa. Consilium: Jurnal Program Studi Bimbingan dan Konseling, 1(2), 13-16.

Rahmaibu, F. H., Ahmadi, F., \& Prasetyaningsih, F. D. (2016). Pengembangan Media Pembelajaran menggunakan Adobe Flash untuk Meningkatkan Hasil Belajar PKn. Jurnal Kreatif: Jurnal Kependidikan Dasar, 7(1), 1-10.

Sadiman, A. (2002). Media Pembelajaran dan Proses Belajar Mengajar, Pengertian Pengembangan dan Pemanfaatannya. Jakarta: Raja Grafindo Persada.

Sartono, Y. (2014). Peningkatkan Tanggungjawab Belajar melalui Layanan Penguasaan Konten dengan Teknik Role Playing. Jurnal Penelitian Tindakan Kelas, 15(4).

Setiyowati, A. J., Indreswari, H., \& Simon, I. M. (2018). Analyzing Classroom Diversity and its Contribution to Multicultural Education in Indonesia. International Conference on Education and Technology (ICET 2018).

Setyowati, A. J., \& Simon, I. M. (2018). Pengembangan Komik Moral sebagai Media Layanan Informasi bagi Siswa SMP. KARYA DOSEN Fakultas Ilmu Pendidikan UM.

Sitompul, D. N. (2015). Pengaruh Penerapan Layanan Bimbingan Kelompok Teknik Role-Playing terhadap Perilaku Solidaritas Siswa dalam Menolong Teman. EduTech: Jurnal Ilmu Pendidikan dan Ilmu Sosial, 1(1), 1-5. 
763 Jurnal Pendidikan, Vol. 5, No. 6, Bln Juni, Thn 2020, Hal 754-763

Sugiyono. (2012). Metode Penelitian Pendidikan. Bandung: Alfabeta.

Utami, N. W., \& Setiyowati, A. J. (2016). Model Permainan Edukasi Peduli Sosial Siswa Sekolah Dasar. Psikopedagogia: Jurnal Bimbingan dan Konseling, 5(2)

Vanments, M. (1983). The Effective Use of Role-Play: A Handbook for Teachers and Trainers. Kogan Page.

Youarti, I. E., \& Hidayah, N. (2018). Perilaku Phubbing sebagai Karakter Remaja Generasi Z. Jurnal Fokus Konseling, 4(1), 143-152. 